\title{
Effect of glyphosate drift on marandu grass
}

\section{Efeito da deriva de glifosato em capim marandu}

\author{
Luciane da Cunha Codognoto ${ }^{1 *} ;$ Thassiane Telles Conde ${ }^{2 ;}$ \\ Glaucia Amorim Faria ${ }^{3}$; Katia Luciene Maltoni ${ }^{3}$
}

\section{Highlights}

Glyphosate drift can have a stimulating or toxic effect on autotrophic organisms.

Glyphosate acts on the photosynthetic route, altering food fractions in the nutrition of ruminants.

Management practices interact beneficially to obtain forage material of nutritional quality.

\begin{abstract}
Glyphosate drift in plants that are not resistant to the herbicide molecule can result in stimulation to certain biological features, characterizing the phenomenon of hormesis. On this basis, productive and chemical traits were evaluated in marandu grass, in a simulation of the drift effect, using sublethal doses of the herbicide glyphosate. The experiment was in laid out in a randomized-block design with split plots in time, in four replicates. The effect of sublethal doses of glyphosate acid equivalent (a.e.) $(21.60,43.20,64.80$, 86.40 and $108.00 \mathrm{~g} \mathrm{ha}^{-1}$ ) and control was evaluated in the plots; and the effect of harvesting at 92, 113, 134 and 155 days after sowing (DAS) the grass was evaluated in the subplots. The Urochloa brizantha cv. Marandu was collected at a height of $0.20 \mathrm{~m}$, at a defoliation interval of 21 days, to estimate production and chemical traits, in experimental plots with a usable area of $7.5 \mathrm{~m}^{2}$. Leaf: stem ratio was influenced by the interaction between the evaluated factors (dose and harvest). Dose fitted a second-order polynomial model, with a hormesis effect of 21.60 to $76.50 \mathrm{~g} \mathrm{ha}^{-1}$ of glyphosate a.e. Harvesting at 134 DAS differed significantly from 92 DAS. The forage yield showed a linear response inversely proportional to the increasing glyphosate doses. There was a polynomial increase in leaf phosphorus content, characterizing hormesis up to the sublethal dose of $72.50 \mathrm{~g}$ a.e. $\mathrm{ha}^{-1}$. Harvest influenced the neutral detergent fiber, acid detergent fiber, lignin and leaf phosphorus contents.
\end{abstract}

Key words: Herbicide. Hormesis. Sublethal dose. Urochloa brizantha.

${ }^{1}$ Eng $^{\text {a Agra }}$, Instituto Federal de Educação, Ciência e Tecnologia de Rondônia, IFRO, Ariquemes, RO, Brasil. E-mail: luciane.codognoto@ifro.edu.br

2 Profa, IFRO, Ariquemes, RO, Brasil. E-mail: thassiane.conde@ifro.edu.gr

3 Profas, Curso de Doutorado do Programa de Pós-Graduação em Agronomia, Universidade Estadual Paulista "Júlio de Mesquita Filho", UNESP, Ilha Solteira, SP, Brasil. E-mail: glaucia.a.faria@unesp.br; katia.maltoni@unesp.br

* Author for correspondence

Received: May 02, 2020 - Approved: Oct. 04, 2020 


\section{Resumo}

A deriva de glifosato em plantas não resistentes à molécula do herbicida pode resultar em estímulo a determinadas características biológicas, caracterizando o fenômeno hormese. Com base nisso, avaliaramse características produtivas e químico-bromatológicas em capim Marandu, simulando efeito de deriva, com doses subletais do herbicida glifosato. O delineamento experimental foi em blocos ao acaso, em parcelas subdivididas no tempo, com quatro repetições. Nas parcelas avaliou-se o efeito de doses subletais do equivalente ácido (e.a.) de glifosato $(21,60,43,20,64,80,86,40$ e 108,00 g e.a. ha-1) e testemunha e, nas subparcelas, o efeito do corte em 92, 113, 134 e 155 dias após semeadura da gramínea (DAS). Em pastagem de Urochloa brizantha cv. Marandu coletou-se a forragem a 0,20 m de altura, com intervalo de desfolha de 21 dias para estimar a produção e análises químico-bromatológicas, em parcelas experimentais com 7,5 m² de área útil. Para relação folha/colmo houve interação dos fatores avaliados (dose e corte). Dose adequouse ao modelo polinomial de segunda ordem, com efeito hormese de 21,60 a $76,50 \mathrm{~g}$ e.a. ha-1 de glifosato. 0 corte em 134 DAS diferiu significativamente sobre o corte em 92 DAS. A produção de forragem apresentou comportamento linear inversamente proporcional ao incremento das doses de glifosato. Houve incremento polinomial no teor de fósforo foliar, caracterizando hormese até a dose subletal 72,50 g e.a. ha-1 . Registrouse efeito do corte sobre fibra em detergente neutro, fibra em detergente ácido, lignina e fósforo foliar.

Palavras-chave: Herbicida. Hormese. Dose subletal. Urochloa brizantha.

\section{Introduction}

With the advent of transgenic crops, the range of the herbicide glyphosate for weed control aroused interest in the drift action of this compound in plants not genetically modified and thus not resistant to the molecule. Very low doses of the herbicide can result in stimulation of certain biological characteristics in conventional plants, in a phenomenon called hormesis (Kappes, Arf, Arf, Gitti, \& Ferreira, 2012; Nascentes et al., 2017). Research points to promising results of the use of sublethal doses of the compound in non-resistant plants as an alternative to increase agricultural production in rice (Gitti et al., 2011), bean (Silva, Arf, Gerlach, Kuryiama, \& Rodrigues, 2012), Crotalaria (Kappes et al., 2012) and sugarcane (Carbonari et al., 2014). Originally, glyphosate is the successor to a growth regulator, and hormesis can be considered an evolutionary response of plants to management-induced disturbances (Duke et al., 2012). This means that very low doses (in general, up to $25 \mathrm{~g}$ a.e. ha ${ }^{1}$, varying between species and stages of development) can induce the accumulation of shikimic acid and promote plant growth, photosynthesis, stomatal opening and seed production. However, how these effects take place is yet to be fully understood (Brito, Tropaldi, Carbonari, \& Velini, 2017).

The herbicide acts on the 5-enolpyruvylshikimate-3-phosphate synthase (EPSPS) component, an enzyme necessary for the photosynthetic process of plants. Therefore, the shikimic acid pathway is unique and essential to plants. Because the glyphosate structure is similar to the enzyme phosphoenolpyruvate-carboxylase (PEPcarboxylase), competition occurs at the binding site in the EPSPs complex, and the interruption of the process impairs the biosynthesis 
of the following amino acids: tryptophan, tyrosine and methionine (Martinez, Loening, \& Graham, 2018). These are responsible for regulating plant growth and defense, altering the contents of tannins, anthocyanins, indole acetic acid (IAA), salicylic acid, lignin, flavones, isoflavones, phenylpropanoids and coumarins (Yamada \& Castro, 2007) and ultimately impairing metabolic processes.

Because glyphosate interferes with vital processes through its herbicidal action on sensitive plants, foliar applications of sublethal doses are assumed to induce a hormesis effect, with morphological and biochemical consequences, in tropical forages. The forage species most commonly used in Brazil is marandu grass (Urochloa brizantha cv. Marandu), which has adapted to the soil-climatic conditions of the Amazon (Teixeira, Pereira, Kikuti, Deminicis, \& Valente, 2018). In Brazil, pasture is the basic feed component of the cattle and buffalo herd due to the lower cost to generate products of high biological value, such as milk and meat. In view of the above-described scenario, this study was developed to evaluate the forage yield and chemical characteristics of a Urochloa brizantha cv. Marandu pasture in response to foliar applications of sublethal doses of glyphosate.

\section{Material and Methods}

The experiment was carried out at the Federal Institute of Education, Science and Technology of Rondônia (IFRO), Ariquemes campus, from January to June 2019. Climatological data during the experimental period were obtained from the automatic station of the National Meteorology Institute (INMET), which is situated $400 \mathrm{~m}$ from the experimental area (Figure 1). The experiment was laid out in a completely randomized design with a factorial arrangement of split plots in time and four replicates. The main factors were arranged into six levels (D), namely, control and five sublethal doses of glyphosate. The subplots constituted harvests $(\mathrm{H})$ of aerial biomass to compose the data, on four successive occasions. 


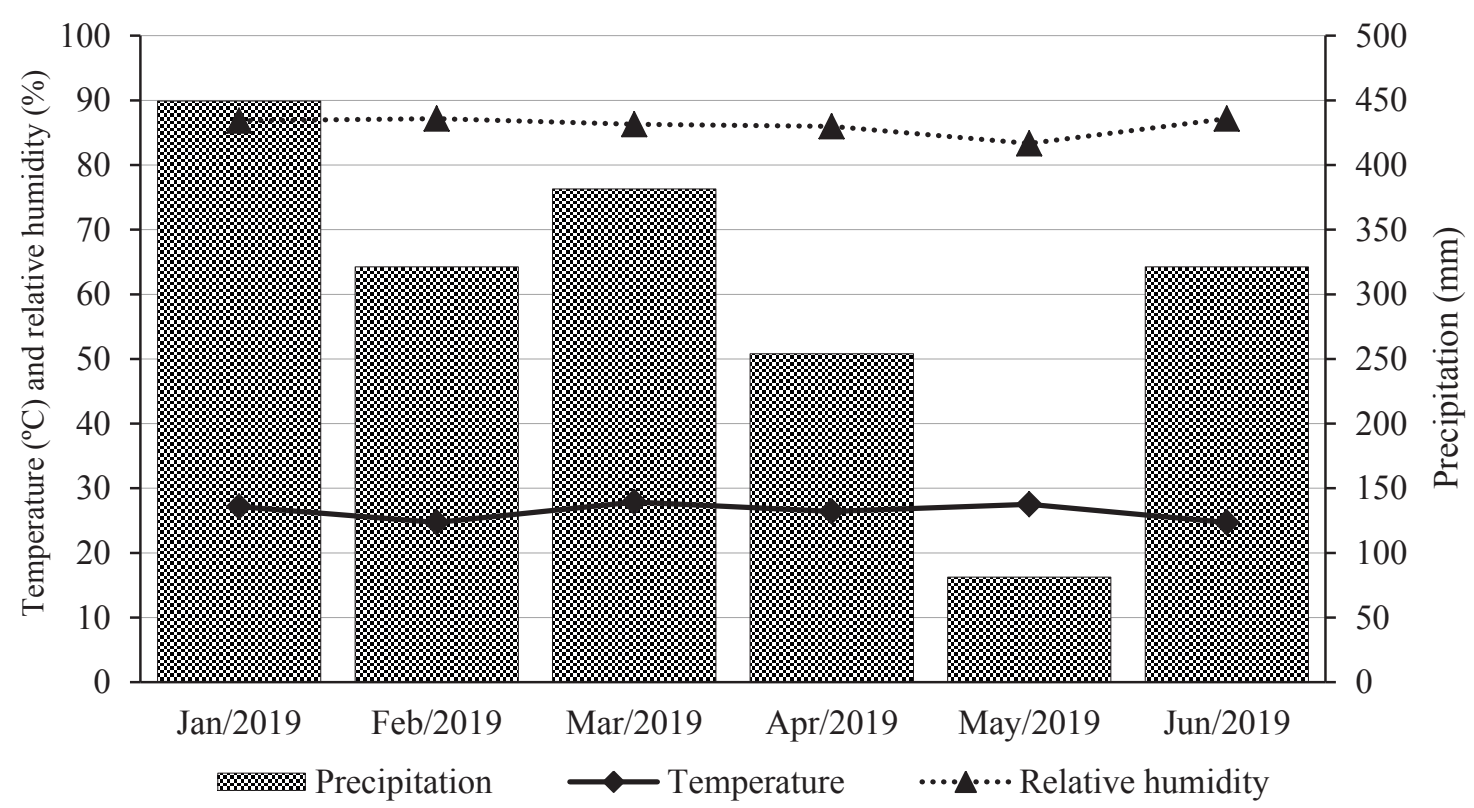

Figure 1. Temperature, relative humidity and monthly precipitation from January to June 2019.

In the area where the experiment was established, cassava had been grown for two consecutive years (2017 and 2018), and soil analysis revealed the following characteristics: $\mathrm{pH}$ in $\mathrm{H}_{2} \mathrm{O}=6.71 ; \mathrm{P}\left(\right.$ Mehlich $\left.^{-1}\right)=2.70 \mathrm{mg} \mathrm{dm}^{-}$ 3; $\mathrm{K}=90 \mathrm{mg} \mathrm{dm}{ }^{-3} ; \mathrm{Ca}^{2+}+\left(\mathrm{KCl} \mathrm{mol} \mathrm{L}{ }^{-1}\right)=2.74$ cmolc $\mathrm{dm}^{-3} ; \mathrm{Mg}^{2+}=1.62$ cmolc $\mathrm{dm}^{-3} ; \mathrm{Al}^{3+}=0$

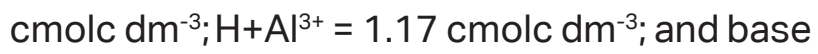
saturation $=79.7 \%$. The soil texture is clayey (720 $\mathrm{g} \mathrm{kg}^{-1}$ of clay). There was no need for liming and the mechanical preparation of the soil was conventional, with plowing (disc plow) and harrowing (leveling-disc harrow) operations for mobilization, clod-breaking and leveling.

Marandu grass seeds acquired from a commercial lot sample (2017/2018 crop; $80 \%$ crop value) were sown on $01 / 11 / 2019$, at a depth of $0.025 \mathrm{~m}$, with rows spaced 0.50 $\mathrm{m}$ apart. At the time of sowing, $270 \mathrm{~kg} \mathrm{ha}^{-1}$ of the N-P-K fertilizer (04-30-16) was applied (Cantarutti, Alvarez, \& Ribeiro, 1999). The experimental plots consisted of seven $4 \mathrm{~m}$ long rows, with a usable area of $7.5 \mathrm{~m}^{2}$.
At 52 and 71 days after sowing (DAS), uniform harvests were performed in the experimental plots in the stratum $0.20 \mathrm{~m}$ above the surface level (Dias, 2012). The experimental period began on $03 / 23 / 2019$. On this occasion, nitrogen fertilizer (urea) was applied, in a total of $50 \mathrm{~kg} \mathrm{ha}^{-1}$ of $\mathrm{N}$ (Cantarutti et al., 1999), and later distributed into three more evaluation harvests: at in 92, 113 and 134 DAS.

Sublethal doses of glyphosate were administered on the seventh day after the evaluation harvest, in the amounts of 21.60, $43.20,64.80,86.40$ and $108.00 \mathrm{~g} \mathrm{ha}^{-1}$ of acid equivalent (a.e.), as well as control treatment. The product used, which contains $356 \mathrm{~g} \mathrm{~L}^{-1}$ of glyphosate a.e., recommends a two-day withdrawal period before grazing. Applications were performed with a backpack sprayer with previous $\mathrm{CO}_{2}$ compression, 2-bar pressure, equipped with a DG11002 VS spray tip, that provides a spray volume of $100 \mathrm{~L} \mathrm{ha}^{-1}$. At the time of application, the adjacent plots were protected with plastic tarps to prevent drift. 
A defoliation frequency of 21 days was adopted, and evaluations were carried out on the 15th day after application of the dose treatment, at 92,113 and 134 DAS. Aerial plant production was measured as the total weight of green forage harvested $0.20 \mathrm{~m}$ above the ground. Aerial fresh mass was determined by weighing and drying leaves and stem + sheath in a forced-air oven at $65^{\circ} \mathrm{C}$ until a constant mass was obtained. In addition, samples were prepared by separating the leaves from stalk + sheath for determining the leaf:stem ratio (L:S) and for leaf analysis, which consisted of leaf dry mass relative to the masses of stem + sheath.

The forage fractions were ground through a Willey knife mill with a 1-mm mesh to measure the contents of dry matter (DM), by oven-drying at $105^{\circ} \mathrm{C}$; crude protein (CP), by the Kjeldahl method; neutral and acid detergent fiber (NDF and ADF), by the Ankom Filter Bag Technique; and lignin, by potassium permanganate oxidation (Detmann et al., 2012). The leaf phosphorus (LP) content was obtained by the metavanadate acid spectrophotometric method (Malavolta, Vitti, \& Oliveira, 1997)

Data were subjected to analysis of variance by the F test, using SISVAR software (Ferreira, 2014). When significant, the effect of glyphosate sublethal dose (D) and the interaction between factors $(D \times H)$ were evaluated by regression analysis. The equation model was selected based on the regression of the highest correlation coefficient $\left(R^{2}\right)$, among the means that were significant by the $F$ test. Harvest effects $(\mathrm{H})$ were compared at $5 \%$ probability by Tukey's test.

\section{Results and Discussion}

Elementary investigation from analysis of variance (Table 1) revealed no effect between glyphosate doses and control (D) and/or evaluation harvest $(\mathrm{H})$ for $\mathrm{CP}$. Thus, the average content obtained (16.89\% DM) was not influenced by $\mathrm{D}$ and/or H. However, the L:S in marandu grass was significantly affected by the interaction (Table 1 ) between $D$ and $H$, characterizing an interdependence between treatments $(\mathrm{D} \times \mathrm{H})$.

The decomposition of the harvest effect (H) at each glyphosate level and control (D) indicated significant differences for L:S (Table 1). With control treatment (without glyphosate application), exclusively, the harvests made at 92, 113 and 155 DAS did not differ from each other, but differed from that at 134 DAS. The glyphosate underdoses (21.60, 43.20, 64.80, 86.40 and $108 \mathrm{~g}$ a.e. ha $^{-1}$ ) provided a lower L:S in the first harvest (92 DAS), which differed from that observed in the harvest performed at 134 DAS. Overall, control and the average of the (five) glyphosate underdoses in the harvest at 134 DAS provided L:S values that exceeded that achieved at 92 DAS, corresponding to 67.23 and $59.87 \%$, respectively. It is therefore assumed that there was an evolutionary process, characterizing disturbances induced by the adopted management (Brito et al., 2017). 
Table 1

Analysis of variance, means and regression of crude protein (CP) and leaf:stem ratio (L:S) of marandu grass treated with sublethal doses of glyphosate (D), in four harvests (H)

\begin{tabular}{|c|c|c|c|c|c|c|}
\hline \multirow{2}{*}{\multicolumn{2}{|c|}{ Variable }} & Dose (D) & Harvest (H) & $\mathrm{D} \times \mathrm{H}$ & \multirow{2}{*}{$\begin{array}{c}C V^{(a)} \\
--(\%)--\end{array}$} & \multirow{2}{*}{ Overall mean } \\
\hline & & \multicolumn{3}{|c|}{------------- F value ------------- } & & \\
\hline CP (\% DM) & & $0.392^{\text {ns }}$ & $0.742^{\text {ns }}$ & $1.005^{\text {ns }}$ & 10.69 & 16.89 \\
\hline L:S & & $2.943^{\text {ns }}$ & $66.148^{* *}$ & $1.922^{*}$ & 11.05 & 2.77 \\
\hline Degrees of freedom & & 5 & 3 & 15 & -------- & -------- \\
\hline \multirow{3}{*}{ Harvest } & \multicolumn{6}{|c|}{ Glyphosate underdose (g a.e. ha ${ }^{-1}$ ) } \\
\hline & 0.00 & 21.60 & 43.20 & 64.80 & 86.40 & 108.00 \\
\hline & \multicolumn{6}{|c|}{ 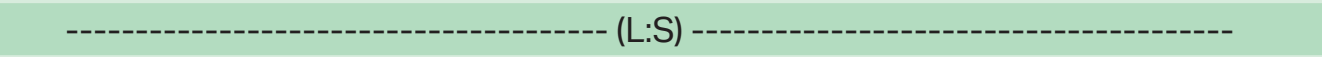 } \\
\hline $092 \mathrm{DAS}^{(\mathrm{b})}$ & $2.40 b^{(c)}$ & $2.16 \mathrm{c}$ & $1.95 \mathrm{c}$ & $1.78 \mathrm{c}$ & $1.99 \mathrm{c}$ & $2.04 \mathrm{~b}$ \\
\hline 113 DAS & $2.91 \mathrm{~b}$ & $3.05 \mathrm{~b}$ & $3.14 \mathrm{ab}$ & $3.13 \mathrm{ab}$ & $3.02 a b$ & $2.66 \mathrm{a}$ \\
\hline 134 DAS & $3.57 \mathrm{a}$ & $3.63 \mathrm{a}$ & $3.53 \mathrm{a}$ & $3.50 \mathrm{a}$ & $3.34 \mathrm{a}$ & $2.75 \mathrm{a}$ \\
\hline 155 DAS & $2.37 \mathrm{~b}$ & $2.16 \mathrm{c}$ & $2.74 \mathrm{~b}$ & $2.90 \mathrm{~b}$ & $2.65 b$ & $2.52 \mathrm{ab}$ \\
\hline \multirow[t]{3}{*}{ Harvest } & \multicolumn{6}{|c|}{ Regression } \\
\hline & \multicolumn{2}{|r|}{ Linear } & Qua & & \multicolumn{2}{|c|}{ Deviation } \\
\hline & \multicolumn{6}{|c|}{--------------------------------- F value ------------------------------- } \\
\hline \multicolumn{2}{|l|}{092 DAS } & $3.521^{\mathrm{ns}}$ & \multicolumn{2}{|c|}{$4.630^{*}$} & \multicolumn{2}{|c|}{$0.211^{\text {ns }}$} \\
\hline \multicolumn{2}{|l|}{113 DAS } & $1.040^{\text {ns }}$ & \multicolumn{2}{|c|}{$5.198^{*}$} & \multicolumn{2}{|c|}{$0.088^{\text {ns }}$} \\
\hline \multicolumn{2}{|l|}{134 DAS } & $14.488^{* *}$ & \multicolumn{2}{|c|}{$5.750^{*}$} & \multicolumn{2}{|c|}{$0.419^{\text {ns }}$} \\
\hline \multicolumn{2}{|l|}{155 DAS } & $0.152^{\text {ns }}$ & \multicolumn{2}{|c|}{$6.028^{*}$} & \multicolumn{2}{|c|}{$0.469^{\text {ns }}$} \\
\hline
\end{tabular}

*, " and ns: significant at $1 \%$ and $5 \%$ and non-significant, respectively, by the $\mathrm{F}$ test.

(a) CV: coefficient of variation.

(b) DAS: days after sowing.

(c) Means followed by the same letter in the column do not differ statistically $(p>0.05)$ by Tukey's test.

Regression analysis for the decomposition of $\mathrm{D}$ in each $\mathrm{H}$ fit the secondorder exponential model (Table 1). The harvest performed at 92 DAS showed an upwardconcave parabola, with a declining behavior occurring at the dose of $80.50 \mathrm{~g}$ a.e. ha-1, providing value equivalent to 1,76 (Figure 2). As for the harvests at 113, 134 and 155 DAS, the slope of the mathematical models showed a limiting effect on the variable. For these, the maximum L:S $(3.23,3.69$ and 2.99$)$ were found under the respective glyphosate doses of $58.99,38.50$ and $76.50 \mathrm{~g}$ a.e. ha-1. Thus, the recorded values are higher than that found by
Lima, Pereira, Sousa, Oliveira and Jakelaitis (2019), who described a mathematical model characterizing an equivalence of 1.11 for the glyphosate doses of 54 and $108 \mathrm{~g}$ a.e. ha $^{-1}$ and control. Additionally, considering the defoliation intensity of $20 \mathrm{~cm}$, Fontes et al. (2014) obtained a lower L:S than the 1.39 recorded in this experiment.

The herbicide reduces the action of the enzyme responsible for the biosynthesis of growth hormone, indole acetic acid (IAA), restricting stem elongation and altering L:S. Gitti et al. (2011) found that up to a glyphosate dose of $78 \mathrm{~g}$ a.e. $\mathrm{ha}^{-1}$, the internodes of treated 
rice plants decreased in size. Therefore, very low doses of glyphosate stimulated the growth and development of the aerial part of the forage, but reduced the stem component between the evaluation harvests, with values higher than those obtained by Sales et al. (2013). When the authors evaluated nitrogen fertilization levels $\left(100,200,300\right.$ and $400 \mathrm{~kg} \mathrm{ha}^{-1}$ of N), a maximum L:S of 1.39 was recorded at the minimum $\mathrm{N}$ dose tested. For the results obtained in the present study, in addition to the fertilization employed (50 kg ha-1 of $\mathrm{N}$ ), the factors of defoliation intensity and frequency $0.20 \mathrm{~m}$ and 21 days, respectively, must be considered integrating parts of the management of the grass. Regrowth vigor was confirmed, ensuring the maintenance of apical meristems, as seen by $L: S$, depending on the harvest intensity. The restoration of forage at the beginning of the defoliation interval consists primarily of the morphological component of leaf, which is stimulated by reduced competition for light and an adequate supply of root reserves (Fontes et al., 2014). As a consequence, the structural characteristics of the forage canopy with the best L:S are directly related to the nutritional value of the produced forage (Maranhão et al., 2010; Santos et al., 2011), mainly due to the reduced/immeasurable dead leaf material obtained in the evaluations.

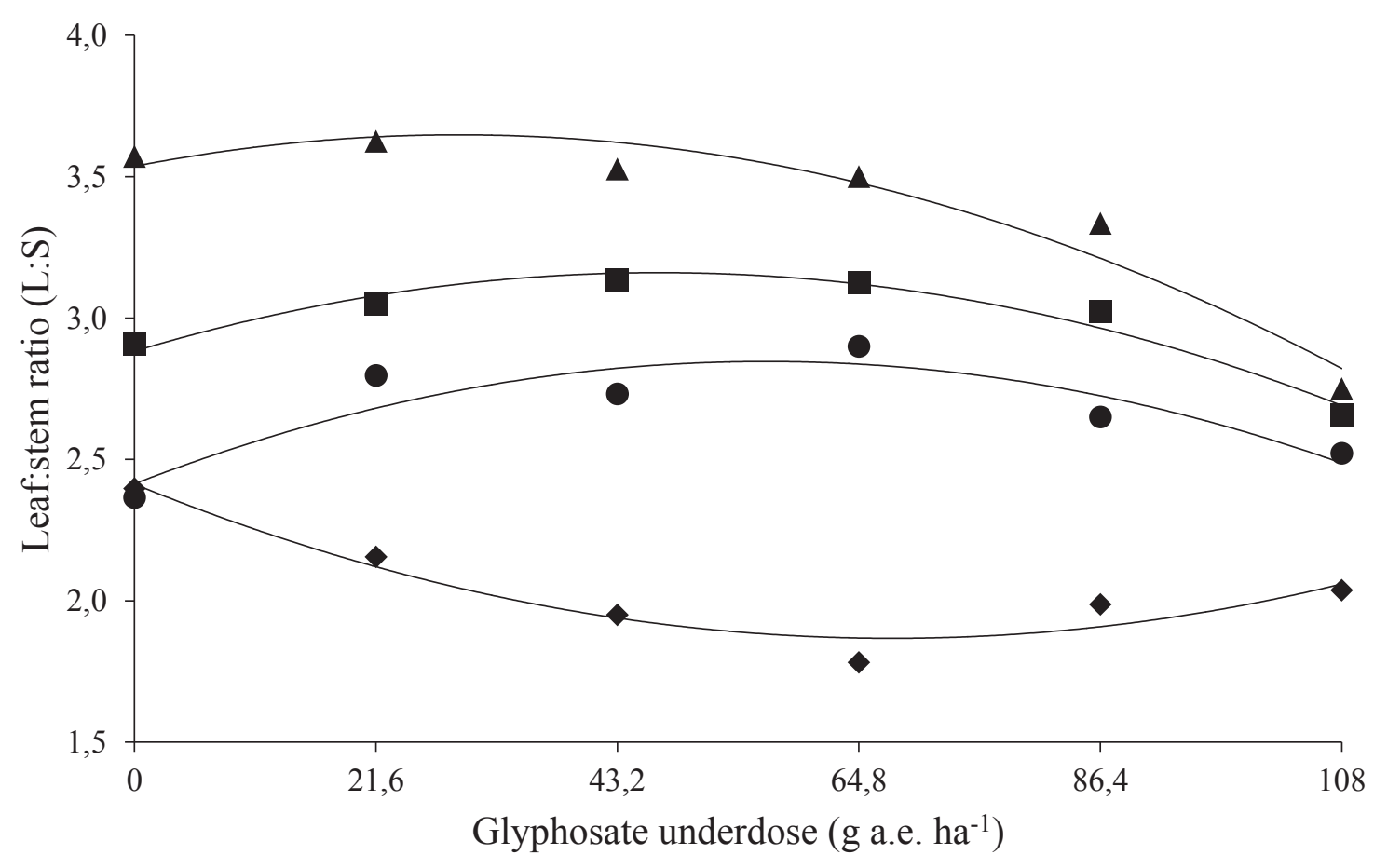

$\begin{array}{ll}\text { Harvest at } 92 \mathrm{DAS} & (\bullet): \hat{\mathrm{y}}=+0.0001 \mathrm{x}^{2}-0.0161 \mathrm{x}+2.4128 ; \mathrm{R}^{2}=0.9281 \\ \text { Harvest at } 113 \mathrm{DAS} & (\boldsymbol{\square}): \hat{\mathrm{y}}=-0.0001 \mathrm{x}^{2}+0.0118 \mathrm{x}+2.8831 ; \mathrm{R}^{2}=0.9593 \\ \text { Harvest at 134 DAS } & (\mathbf{A}): \hat{\mathrm{y}}=-0.0001 \mathrm{x}^{2}+0.0077 \mathrm{x}+3.5371 ; \mathrm{R}^{2}=0.9415 \\ \text { Harvest at 155 DAS } & (\bullet): \hat{y}=-0.0001 \mathrm{x}^{2}+0.0153 \mathrm{x}+2.4139 ; \mathrm{R}^{2}=0.8144\end{array}$

Figure 2. Leaf:stem ratio of marandu grass exposed to underdoses of glyphosate and control, in four evaluation harvests. 
Preliminary analysis of forage yield (FY) and LP revealed isolated effects for the $\mathrm{D}$ and $\mathrm{H}$ treatments (Table 2). For $\mathrm{FY}$, the test of means of $\mathrm{H}$ as a source of variation showed superiority at 92 DAS, which differed significantly from the subsequent harvests (Table 2). There was limited yield in the harvest performed at 113 DAS and subsequent harvests, characterizing a yield reduction equivalent to $53.37 \%$ of that recorded at 92 DAS. In isolation, regression analysis for $D$ fit the negative linear mathematical model (Table 2), in which the sequential progression of 21.60 $\mathrm{g}$ of glyphosate a.e. ha-1 applied resulted in a behavior inversely proportional to that of LP (Figure 3A). The mathematical model predicts a production loss equivalent to $77.94 \mathrm{~kg} \mathrm{ha}^{-1}$ of DM for each gram of glyphosate applied to the forage. However, Nascentes, Fagan, Soares, Oliveira and Brunelli (2015) found a hormesis effect in an established pasture of marandu grass, where the nonlinear regression model characterized an approximate $32 \%$ productive stimulus with a glyphosate underdose of $10.50 \mathrm{~g}$ a.e., in a harvest performed 15 days after application. In sugarcane, Carbonari et al. (2014) also found a hormesis effect for the biomass of the aerial part of the plants with glyphosate doses in the range 7.20 and 36.00 $\mathrm{g}$ a.e. $\mathrm{ha}^{-1}$, at 21 days after application. Thus, the initial dose used in this experiment may not have been adequate to evidence a variable hormesis effect. However, the deleterious effects of glyphosate did not result in chlorosis or some level of phytotoxicity.

The mean LP content exhibited a significant difference (Table 2), especially between the harvests at 92 and 134 DAS. A low LP was found in the harvest at 92 DAS, corresponding to $80.77 \%$ of that obtained at 134 DAS. For this variable, regression analysis fitted the second-order polynomial model (Table 2). The slope coefficient of the model predicts restrictions to LP with increasing glyphosate doses (Figure 3B). In this case, there would be a foliar increase of the element up to the glyphosate dose of $72.50 \mathrm{~g}$ a.e. ha1 , reaching $4.13 \mathrm{~g} \mathrm{~kg}^{-1}$ of DM. Nonetheless, the effects seen here are not explained by the inhibition of EPSPS, warranting a specific investigation of the observed situation. The interaction between phosphate and glyphosate transporters is not yet fully elucidated, as neither are other chemical mechanisms for the degradation of phosphonic acids. 


\section{Table 2}

Analysis of variance, mean and regressions of forage yield (FY) and leaf phosphorus content (LF) of marandu grass treated with sublethal doses of glyphosate (D), in four harvests (H)

\begin{tabular}{|c|c|c|c|c|c|}
\hline \multirow{2}{*}{ Variable } & Dose (D) & Harvest (H) & $\mathrm{D} \times \mathrm{H}$ & \multirow{2}{*}{$\begin{array}{c}C^{(a)} \\
--(\%)--\end{array}$} & \multirow{2}{*}{ Overall mean } \\
\hline & \multicolumn{3}{|c|}{------------- F value ------------- } & & \\
\hline $\mathrm{FY}\left(\mathrm{kg} \mathrm{ha}^{-1} \mathrm{DM}\right)$ & $15.897^{* *}$ & $51.203^{* *}$ & $1.104^{\text {ns }}$ & 21.07 & 1164.38 \\
\hline LF ( $\left.\mathrm{g} \mathrm{kg}^{-1} \mathrm{DM}\right)$ & $25.620^{* *}$ & $16.745^{* *}$ & $0.997^{\text {ns }}$ & 12.34 & 3.52 \\
\hline Degrees of freedom & 5 & 3 & 15 & -------- & -------- \\
\hline \multirow{2}{*}{ Variable } & \multicolumn{5}{|c|}{ Harvest } \\
\hline & $092 \mathrm{DAS}^{(\mathrm{b})}$ & 113 DAS & 134 DAS & & 155 DAS \\
\hline FY (kg ha-1 DM) & $1552.75 a^{(c)}$ & $828.75 \mathrm{c}$ & $1150.18 b$ & & $1125.88 b$ \\
\hline LF (g kg-1 DM) & $3.15 \mathrm{c}$ & $3.47 \mathrm{bc}$ & $3.90 \mathrm{a}$ & & $3.57 b$ \\
\hline \multirow[t]{3}{*}{ Variable } & \multicolumn{5}{|c|}{ Regression } \\
\hline & Linear & \multicolumn{2}{|c|}{ Quadratic } & \multicolumn{2}{|c|}{ Deviation } \\
\hline & \multicolumn{5}{|c|}{------------------------------- F value ---------------------------- } \\
\hline FY (kg ha-1 DM) & $72.339^{* *}$ & \multicolumn{2}{|c|}{$1.680^{\text {ns }}$} & \multicolumn{2}{|c|}{$1.823^{\text {ns }}$} \\
\hline LF (g kg-1 DM) & $51.912^{* *}$ & \multicolumn{2}{|c|}{$71.535^{* *}$} & \multicolumn{2}{|r|}{$1.1551^{\text {ns }}$} \\
\hline
\end{tabular}

"* , and ns: significant at $1 \%$ and $5 \%$ and non-significant, respectively, by the $\mathrm{F}$ test.

(a) $\mathrm{CV}$ : coefficient of variation.

(b) DAS: days after sowing.

(c) Means followed by the same letter in the column do not differ statistically ( $p>0.05)$ by Tukey's test. 
(A)

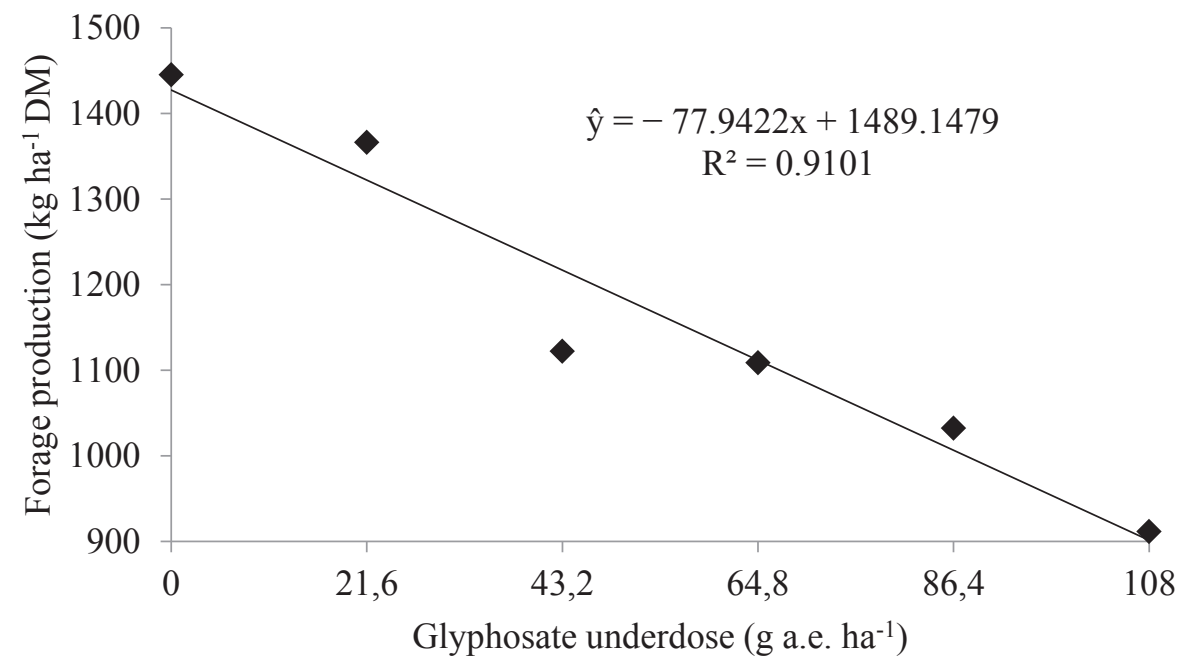

(B)

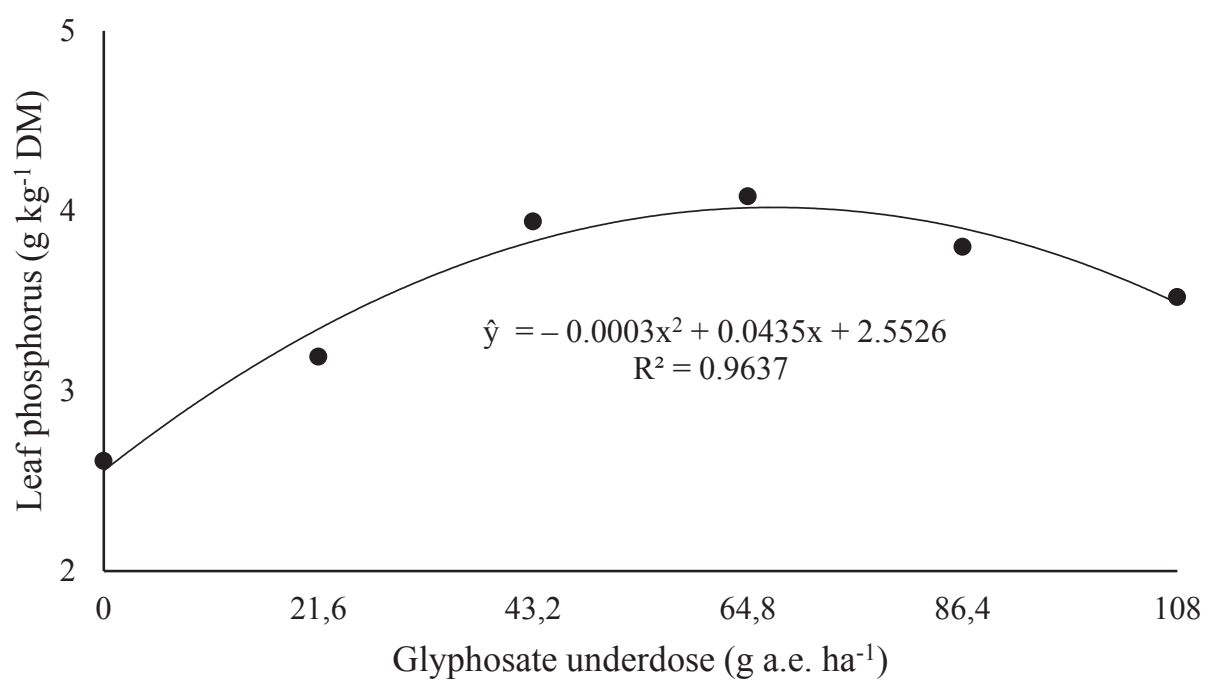

Figure 3. Forage yield (A) and leaf phosphorus content (B) of marandu grass as a function of glyphosate underdoses and control.

In forages, even Brachiaria, which are less phosphorus-demanding species, the element is essential to cell division and morphogenetic processes, especially the restoration of the forage canopy, an indispensable component to grazing. As a result, the structural characteristics of the pasture are directly affected (Porto et al., 2012).
Analysis of variance revealed $a$ significant effect of $\mathrm{H}$ for NDF, ADF and lignin (Table 3). The effect of $\mathrm{H}$ on NDF resulted in a lower content in the material harvested at 113 DAS, which did not differ from those at 92 and 134 DAS (Table 3). However, the obtained NDF contents are not limiting to forage intake. The limit of $65 \%$ of NDF in the DM of tropical 
forages, under a defoliation frequency of 30 days, characterizes good nutritional value of the forage, favoring animal performance and productivity on pasture (Alencar et al., 2010; Hanisch, Balbinot, \& Vogt, 2017).

Table 3

Analysis of variance, means and regressions of neutral detergent fiber (NDF), acid detergent fiber (ADF) and lignin production in marandu grass treated with sublethal doses of glyphosate (D), in four harvests $(\mathrm{H})$

\begin{tabular}{|c|c|c|c|c|c|}
\hline \multirow{2}{*}{ Variable } & Dose (D) & Harvest (H) & $\mathrm{D} \times \mathrm{H}$ & \multirow{2}{*}{$\begin{array}{c}\mathrm{CV}^{(\mathrm{a})} \\
--(\%)--\end{array}$} & \multirow{2}{*}{ Overall mean } \\
\hline & \multicolumn{3}{|c|}{-------------- F value ------------- } & & \\
\hline NDF (\% DM) & $3.380^{\text {ns }}$ & $9.299^{* *}$ & $0.683^{\text {ns }}$ & 6.91 & 59.69 \\
\hline ADF (\% DM) & $0.115^{\mathrm{ns}}$ & $10.575^{\star \star}$ & $1.366^{\text {ns }}$ & 4.96 & 29.30 \\
\hline Lignin (\% DM) & $0.454^{\text {ns }}$ & $20.288^{* *}$ & $1.399^{\text {ns }}$ & 12.04 & 2.69 \\
\hline Degree of freedom & 5 & 3 & 15 & -------- & -------- \\
\hline \multirow{2}{*}{ Variable } & \multicolumn{5}{|c|}{ Harvest } \\
\hline & $092 \mathrm{DAS}^{(b)}$ & 113 DAS & 134 DAS & & 155 DAS \\
\hline NDF (\% DM) & $59.75 a b^{(c)}$ & $58.08 b$ & $59.51 \mathrm{ab}$ & & $61.42 \mathrm{a}$ \\
\hline ADF (\% DM) & $31.09 a$ & $29.34 \mathrm{ab}$ & $27.32 \mathrm{~b}$ & & $29.45 a$ \\
\hline Lignin (\% DM) & $2.41 \mathrm{c}$ & $2.64 \mathrm{bc}$ & $2.69 \mathrm{~b}$ & & $3.01 \mathrm{a}$ \\
\hline
\end{tabular}

As with NDF, there was an effect of $\mathrm{H}$ on ADF. The lowest ADF content, recorded in the harvest at 134DAS, did not differ from that found at 113 DAS (Table 3). In forages, ADF values around $30 \%$ are considered ideal for animal intake (Miranda et al., 2018). The ADF contents reported in this study are consistent with the digestibility of the forage, indicating low levels of lignified components, which is favorable to the digestibility and use of the ingested plant (Oliveira, Bonfim-Silva, Silveira, \& Monteiro, 2010). Meschede, Velini, Carbonari and Moraes (2011) tested the effect of glyphosate on chemical variables of $U$. decumbens, with the initial glyphosate dose of $32 \mathrm{~g}$ a.e. $\mathrm{ha}^{-1}$ and control treatment, and obtained ADF contents of 40.50 and $42.50 \%$, respectively, with no hormesis effect for the variable.

The defoliation $(\mathrm{H})$ of the forage provided an increase in the lignin contents, which resulted in a decline in forage quality, especially in the harvest performed at 155 DAS (Table 3). This nutrient prevents the enzymatic access of ruminal microorganisms to the cellulose and hemicellulose fractions of marandu grass as well as other potentially digestible nutrients, namely, soluble carbohydrates, proteins, minerals and vitamins (Velásquez et al., 2010). In this way, successive applications characterized a plant growth regulation behavior, since the inhibition of the enzyme EPSPs affects lignin production, 
interfering with carbon metabolism, prioritizing lignification and depressing the metabolism of non-structural carbohydrates.

Therefore, the evaluation harvest performed at the defoliation intensity and frequency of $0.20 \mathrm{~m}$ and 21 days, respectively, resulted in adequate values for the nutritional quality variables of the forage, i.e., NDF, ADF and lignin. The management did not result in the appearance of senescent leaves or dead material. Accordingly, the obtained L:S is sufficient for forage with high crude protein content, digestibility and intake, increasing the prehension of forage by the animal and consequently improving its performance.

\section{Conclusions}

The glyphosate underdoses tested (up to $108 \mathrm{~g} \mathrm{ha}^{-1}$ of glyphosate acid equivalent) do not increase forage production in marandu grass.

Increasing doses of glyphosate acid equivalent, up to $76.50 \mathrm{~g} \mathrm{ha}^{-1}$, induce an increase in the leaf:stem ratio of the grass.

Glyphosate acid equivalent underdoses up to $72.50 \mathrm{~g} \mathrm{ha}^{-1}$ provide an increase in the leaf phosphorus content of the forage.

Harvesting enhances the leaf:stem ratio and forage quality (neutral detergent fiber, acid detergent fiber, lignin and leaf phosphorus contents).

\section{Acknowledgments}

The authors thank Sementes Oeste Paulista (SOESP) and agronomic engineer Andreza P. S. Cruz, for providing the materials for the development of the experiment.

\section{References}

Alencar, C. A. B., Oliveira, R. A., Cóser, A. C., Martins, C. E., Cunha, F. F., Figueiredo, J. L. A.,... Leal, B. G. (2010). Valor nutritivo de gramíneas forrageiras tropicais irrigadas em diferentes épocas do ano. Pesquisa Agropecuária Tropical, 40(1), 20-27. doi: 10.5216/pat.v40i1.3994

Brito, I. P. F. S., Tropaldi, L., Carbonari, C. A., \& Velini, E. D. (2017). Hormetic effects of glyphosate on plants. Pesticide Management Science, 74(5), 1064-1070. doi: $10.1002 / p s .4523$

Cantarutti, R. B., Alvarez, V. V. H., \& Ribeiro, A. C. (1999). Pastagens. In A. C. Ribeiro, P. T. G. Guimarães, \& V. V. H. Alvarez (Eds.), Comissão de fertilidade do solo do Estado de Minas Gerais. Recomendação para o uso de corretivos e fertilizantes em Minas Gerais (pp. 332-341). Viçosa, MG: EPAMIG.

Carbonari, C. A., Gomes, G. L. G. C., Velini, E. D., Machado, R. F., Simoes, P. S., \& Macedo, G. C. (2014). Glyphosate effects on sugarcane metabolism and growth. American Journal of Plant Sciences, 5(24), 3585-3593. doi: 10.4236/ajps.2014.524374

Detmann, E., Souza, M. A., Valadares, S. C., Fo., Queiroz, A. C., Berchielli, T. T., Saliba, E. O. S.,... Azevedo, J. A. G. (2012). Métodos para análise de alimentos - INCT - Ciência Animal. Visconde do Rio Branco: Suprema.

Dias, M. B., Fo. (2012). Formação e manejo de pastagens. (Comunicado Técnico, 235). Belém, PA: EMBRAPA Amazônia Oriental. EMBRAPA Amazônia Oriental.

Duke, S. O., Lydon, J., Koskinen, W. C., Moorman, T. B., Chaney, R. L., \& Hammerschmidt, R. (2012). Glyphosate effects on plant mineral nutrition, crop rhizosphere microbiota, and plant disease in glyphosate-resistant crops. Journal of Agricultural and Food 
Chemistry, 60(42), 10375-10397. doi: 10. 1021/jf302436u

Ferreira, D. F. (2014). SISVAR: a guide for its bootstrap procedures in multiple comparisons. Ciência Agropecuária, 38(2), 109-112. doi: 10.1590/S141370542014000200001

Fontes, J. G. G., Fagundes, J. L., Backes, A. A., Barbosa, L. T., Cerqueira, E.S.A., Silva, L. M.,... Vieira, J. S. (2014). Herbage accumulation in Brachiaria brizantha cultivars submitted to defoliation intensities. Semina: Ciências Agrárias, 35(3), 1425-1438. doi: 10.5433/1679-0359.2014v35n3p1425

Gitti, D. C., Arf, O., Peron, I. B. G., Portugal, J. R., Corsini, D. C. D. C., \& Rodrigues, R. A. F. (2011). Glyphosate como regulador de crescimento em arroz de terras altas. Pesquisa Agropecuária Tropical, 41(4), 500-507. doi: 10.5216/pat.v41i4.10160

Hanisch, A. L., Balbinot, A. A., Jr., \& Vogt, G. A. (2017). Desempenho produtivo de Urochloa brizantha cv. Marandu em função da inoculação com Azospirillum e doses de nitrogênio. Revista Agro@ mbiente On-line, 11(3), $200 . \quad$ doi: 10.18227/1982-8470ragro.v11i3.3916

Kappes, C., Arf, M. V., Arf, O., Gitti, D. C., \& Ferreira, J.P. (2012). Resposta da crotalária à épocas e subdoses de aplicação de glifosato. Bioscience Journal, 28(3), 373383. doi: 10.5216/pat.v41i4.10160

Lima, S. F., Pereira, L. S., Sousa, G. D., Oliveira, G. S., \& Jakelaitis, A. (2019). Supressão de Urochloa brizantha e U. ruziziensis por subdodoes do glicosato. Revista Caatinga, 32(3), 581-589. doi: 10.1590/ 1983-21252019v32n302rc

Malavolta, E., Vitti, G. C., \& Oliveira, S. A. (1997). Avaliação do estado nutricional das plantas: princípios e aplicações (2a ed., rev. e atual.). Piracicaba: POTAFÓS.
Maranhão, C. M. A., Bonomo, P., Pires, A. J. V., Costa, A. C. P. R., Martins, G. C. F., \& Cardoso, E. O. (2010). Características produtivas do capim-braquiária submetido a intervalos de cortes e adubação nitrogenada durante três estações. Acta Scientiarum. Animal Sciences, 32(4), 375-384. doi: 10.4025/ actascianimsci.v32i4.8574

Martinez, D. A., Loening, U. E., \& Graham, M. C. (2018). Impacts of glyphosate-based herbicides on disease resistance and health of crops: a review. Environmental Sciences Europe, 30(2), 14. doi: 10.11 86/ s12302-018-0131-7

Meschede, D. K., Velini, E. D., Carbonari, C. A., \& Moraes, C. P. (2011). Efeitos do glyphosate nos teores de lignina, celulose e fibra em Brachiaria decumbens. Revista Brasileira de Herbicidas, 10(1), 57-63. doi: 10.7824/ rbh.v10i1.77

Miranda, C. C. B., Florentino, L. A., Rezende, A. V., Nogueira, D. A., Leite, R. F., \& Naves, L. P. (2018). Desenvolvimento de Urochloa brizantha adubada com fonolito e inoculada com bactérias diazotróficas solubilizadoras de potássio. Revista de Ciências Agrárias, 41(3), 41-50. doi: 10.19084/RCA17011

Nascentes, R. F., Carbonari, C. A., Simões, P. S., Brunelli, M. C., Velini, E. D., \& Duke, S.O. (2017). Low doses of glyphosate enhance growth, $\mathrm{CO}^{2}$ assimilation, stomatal conductance and transpiration in sugarcane and eucalyptus. Pest Management Science, 74(5), 1197-1205. doi: 10.1002/ps.4606

Nascentes, R. F., Fagan, E. B., Soares, L. H., Oliveira, C. B., \& Brunelli, M. C. (2015). Hormesis de Glyphosate em Brachiaria brizanta cv. Marandu. Cerrado Agrociências, (6), 55-64. 
Oliveira, D. A., Bonfim-Silva, E. M., Silveira, C. P., \& Monteiro, F. A. (2010). Valor nutritivo do capim-braquiária no primeiro ano de recuperação com aplicações de nitrogênio e enxofre. Revista Brasileira de Zootecnia, 39(4), 716-726. doi: 10.1590/ S1516-35982010000400004

Porto, E. M. V., Alves, D. D., Vitor, C. M. T., Gomes, V. M., Silva, M. F., \& David, A. M. S. S. (2012). Rendimento forrageiro da Brachiaria brizantha cv. Marandu submetida a doses crescentes de fósforo. Revista Scientia Agraria Paranaensis, 11(3), 25-34. doi: 10.18188/sap.v11i3.4238

Sales, E. C. J., Reis, S. T., Monção, F. P., Antunes, A. P. S., Oliveira, E. R., Matos, V. M.,... Delvaux, A. S. (2013). Produção de biomassa de capim-marandu submetido a doses de nitrogênio em dois períodos do ano. Revista Agrarian, 6(22), 486-499. Disponível em: https://ojs.ufgd.edu.br/ index.php/agrarian/article / view/2114

Santos, M. E. R., Fonseca, D. M., Magalhães, M. A., Silva, S. P., Casagrande, D. R., Balbino, E. M., \& Gomes, V. M. (2011). Estrutura e valor nutritivo do pasto diferido de Brachiaria decumbens cv. Basilisk durante o período de pastejo. Revista Brasileira de Agropecuária Sustentável, 1(1), 112-122. Recuperado de repositorio.ufla.br/jspui/ handle/1/15307
Silva, J. C., Arf, O., Gerlach, G. A. X., Kuryiama, C. S., \& Rodrigues, R. A. F. (2012). Efeito hormese de glyphosate em feijoeiro. Pesquisa Agropecuária Tropical, 42(3), 295-302. doi: 10.1590/S1983-4063201 2000300008

Teixeira, R. N. V., Pereira, C. E., Kikuti, H., Deminicis, B. B., \& Valente, T. N. P. (2018). Productive capacity of Brachiaria brizantha (Syn. Urochloa brizantha) cv. Marandu subjected to liming and nitrogen application. African Journal of Agricultural Research, 13(36), 1901-1906. doi: 10.5897/AJAR 2018.13266

Velásquez, P. A. T., Berchielli, T. T., Reis, R. A., Rivera, A. R., Dian, P. H. M., \& Teixeira, I. A. M. A. (2010). Composição química, fracionamento de carboidratos e proteínas e digestibilidade in vitro de forrageiras tropicais em diferentes idades de corte. Revista Brasileira de Zootecnia, 39(6), 1206-1213. doi: 10.1590/S151635982010000600007

Yamada, T., \& Castro, P. R. C. (2007). Efeitos do glifosato nas plantas: implicações fisiológicas e agronômicas. (Boletim Técnico, 119). Piracicaba: Informações Agronômicas. 